\title{
NATIONAL PRIORITIES VS ECONOMIC ADVISABILITY: SEARCH OF RUSSIAN INTEGRATION LIMITS INTO WORLD FOOD MARKET
}

\author{
Baryshnikova N.A. \\ Saratov State Law Academy, \\ Saratov, 410056, Russia
}

Sukhorukova A.M.

Saratov Socio-Economic institute of

Plekhanov Russian University of Economics

Saratov, 410003, Russia

\author{
Kireeva N.A. \\ Saratov Socio-Economic institute of \\ Plekhanov Russian University of Economics \\ Saratov, 410003, Russia \\ Bagautdinova N.G. \\ Kazan Federal University \\ Institute of Management, Economics and Finance \\ Kazan, 420012, Russia
}

\begin{abstract}
Problems of integration of the Russian food system into world system in accordance with its conjuncture are viewed in the article. Indicator analysis of food production systems development of world countries was performed on the basis of multidimentional grouping that allowed one to identify prospects for Russian food producers in the world market. Strategic alternatives of import substituting and export-oriented growth by the example of single product markets are determined. Evaluation of the amount of possible import substitution volume and export in terms of product groups is given in the article. It is concluded that positive effect of food embargo has temporary influence; therefore, top priority should be given to creation of effective economic and financial levers of production development, domestic demand restoring, and stimulating of export activity of Russian enterprises.
\end{abstract}

Keywords - import substitution, food market, agriculture, food security

\section{INTRODUCTION}

During previous three years, environment in which the Russian food system is functioning has been transformed substantially. The key factors of its long-term and short-term development are preservation of crisis tendencies in economy, sanctions and food embargo prolongation and enforcement of protectionism to food producers. Under condition of progressing globalization, it is required to form new priorities of national food policy. The major problem to be solved is ratio of food sovereignty and economic advisability, determining optimal limits of Russian integration into the world food market.

There are a lot of studies of food systems in global world performed by researchers-economists [Ericksen, Ingram, Liverman, 2009], [Reilly, Willenbockel, 2010], [Godfray, Crute, Haddad, 2010], [Heller, 2003]. Based on systematization of research in import substitution sphere [Prebish, 1950], [Bauer, 1972], we come to conclusion that there are two absolutely different approaches. According to the first one - import substitution is growth of domestic production. According to the second one - import substitution is import limitation. The aim of the article is to find the consensus between these two approaches and make a forecast of import substitution of the food system in Russia and optimal limits of its integration into the world food market in accordance with its conjuncture.

\section{METHOD}

Research methodology of possibilities and particular ways of import substitution in the food market take into consideration characteristics of research object, patterns of its functioning and peculiarities of governmental regulation. Most important methodological principles and approaches are the following.

The theoretical basis for research is neoclassical synthesis, in the frames of which market equilibrium means the equation between demand and supply of a good, considering its production and export-import flows:

$$
D_{i}=S_{i}+E x_{i}-\operatorname{Im}_{i}
$$

where $\mathrm{D}_{\mathrm{i}}-$ demand for food;

$\mathrm{S}_{\mathrm{i}}$ - food supply;

$\mathrm{Ex}_{\mathrm{i}}$ - food export;

$\mathrm{Im}_{\mathrm{i}}-$ food import.

2. The most important methodological approach to this research is consideration of complex of internal and external determinants of the country's food system and its integration 
into global world food market under conditions of progressing international integration. Globalization results in great changes in foreign trade, value-added chain and food security (both global and in every single country) [Montalbano, Nenci, Salvatici, 2015], [Griffith, Baker, Fleming, Mounter, 2016].

3. Two methods revealing perspective world market segments for Russian food producers are applied to this research. First, it is the indicator analysis of food systems development in world countries, where the main instrument is multidimentional grouping. The second method is comparative analysis of world food segments from the point of view of their attractiveness to Russia.

4. Productive principle lies in defining strategic alternatives of import substitution and export-oriented growth, where goods are classified in such way: import volume and its percentage in food import structure; import share in resources of a particular product; internal potential and competitive advantages for an increase in domestic production and import substitution.

\section{RESULT}

According to FAO UNO statistics, population of our planet is about 7.3 billion people, 3 billion of which (about a half) belongs to rural area. World size of fields and pastures was 2.7 billion hectares in 2015, and world food production -2247 billion dollars. In GDP structure, world average share of value added agricultural products was 4 per cent. According to FAO, world food export-import flows dramatically increase. Thus, in 2014 in comparison with 1990 food export grew 4.4 times and made up 945.5 billion dollars, import grew 4.1 times (up to 966.9 billion dollars).

Russian population is about 2 per cent from world population whereas cropland share of our country makes 3.24 per cent. It means that resource potential of our country theoretically allows one to increase foods production volume, providing them not only on domestic market, but also on the world market [Wehrheim, Wobs, 2005]. The necessary conditions for this are labor efficiency growth in agricultural sector, increase in domestic food competitiveness and achievement of advanced growth rates of food export compared to import (their ratio in the world is around 1). In this case strengthening of Russian positions in the world market becomes possible.

To prove country typology from the point of view their involvement in world trade of agricultural goods and food and determine the role and place of Russia in the world market, we examined world countries on the basis of FAO (Food and Agricultural Organization of the United Nations) data. We selected 110 countries (with population of more than 1 million people). With the help of cluster analysis (k-average method) we performed grouping of countries in many dimensions based on four relative indicators:

- fields and pastures area per head (hectare/per head) characterizes provision with resources of national food system;
- production of value-added in agriculture - characterizes labor efficiency in agriculture (dol/per person)

- food production per head (dol/per person) characterizes relative output of domestic food production;

- ratio of food export and import characterizes the level of economic independence of the country in food production sphere.

Division of countries into clusters was made on the basis of national and world average indicators comparison. After 4 iterations, world countries were divided into 5 clusters. Their analysis pointed out that total food sovereignty, as well as absolute food dependence under conditions of the contemporary system of world economic relations, is not only impossible, but inexpedient.

Countries of the first cluster (Belgium, Finland, France, Island, Netherland, Norway, Japan, Saudi Arabia) on average are not very well provided with resources and are characterized by absence of favorable conditions for development of all of agricultural production branches. Nevertheless, today in the food sector of these countries we may see the highest level of labor efficiency (it is mostly achieved by concentration on labor-intensive types of food production, for example, fish catch). Therefore, having relatively narrow specialization in food production and supplying limited assortment of goods to the world market, these countries depend much on food import.

Countries of the second cluster make "core" of world food system, having resources for highly effective production of agricultural products and providing with food not only own population, but also other country's. This cluster includes Australia, Germany, New Zealand, Great Britain, Canada, the USA and etc. These countries take advantages of international labor division at their maximum - specialize in food products with minimum production costs, and, at the same time, import, necessary for domestic needs, food.

Countries of the third cluster are well provided with resources for agriculture, provide high level of food production per head even within average labor efficiency (Argentina, Bulgaria, Greece, Hungary, Malaysia, Slovakia, Slovenia). They are net-exporters of food: ratio of export and import to cluster makes 3.54 .

The fourth cluster is provided with land as well (Russia and 26 more countries). However, low labor efficiency (more than twice in comparison with world average) does not allow these countries to reach a comparable with developed countries level of food production.

Finally, countries of the fifth cluster are mainly less developed (the poorest countries of Asia and Africa). Having low resource provision and extremely low labor efficiency in the food production sector of economy, these countries appear unable to provide population with sufficient quantity and procurable of high quality food. As a result, even despite a considerable share of import in commodity resource of food, indicators of hunger in most of these countries are behind the critical index. 
Therefore, the place of Russia in the global system of food production and distribution is not yet significant. Being in the top 10 list of biggest producers of some types of food by production volume in natural equivalent (grain, meat, sugar), our country lags behind developed countries both in the level of average food production per capita and in labor efficiency.

Positive effect of globalization on Russian economy is in expansion of foreign markets for Russian goods and improvement of export structure [Gallyamova, Toumashev, Malaev 2014]. However, the recognized internal system constraints and new threats impact do not allow one to realize internal potential for achieving the balance of demand and supply of food and agricultural products.

Mass food import, maximum of which took place in 199697, determined depressed condition of some agricultural branches and food-processing industry, which Russia is not able to overcome even now. Beginning with year 2000, growth of food export is seen, and it increased 10 times to 2015. Nevertheless, food import considerably exceeded its export. We can see a considerable share of import if we compare volume of domestic agricultural food production and import (Figure 1). Food accounted for 13.7 per cent in the import structure.

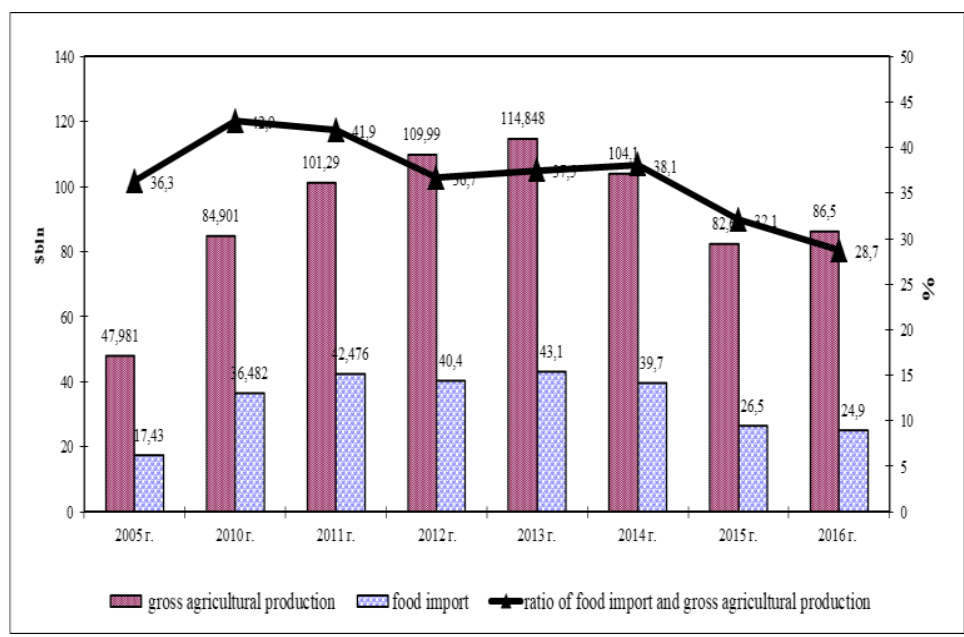

Fig. 1. Import capacity of agricultural sector of Russia in 2005-2015

Nowadays there is still a considerable import share in resources in such types of food as beef, butter and cheese, dry milk and cream. If the import share of beef in resources was 62 per cent in 2008 and 43 per cent - in 2016, cheese - 41 per cent in 2005 and 24 per cent - in 2016; in dry milk market there was a double increase of this indicator.

Based on the assessment of internal development potential and possibilities of integration into world food market, typology of product groups was developed, depending either on import substitution, or integration into world food market (table 1). Internal potential was determined due to estimation of production growth rate, capacity of the sectoral market from the domestic demand side, dynamics of foodstuffs consumption and considering complementarity of the products (according to 2010-2015 data).
TABLE I. THE RECOMMENDED IMPORT SUBSTITUTION STRATEGY / INTEGRATION INTO THE WORLD FOOD MARKET

\begin{tabular}{|l|c|c|c|l|}
\hline \multicolumn{1}{|c|}{ Product } \\
group & $\begin{array}{c}\text { Import } \\
\text { in 2015, } \\
\text { million } \\
\text { dollars. }\end{array}$ & $\begin{array}{c}\text { Import } \\
\text { share in } \\
\text { resource, } \\
\text { \% }\end{array}$ & $\begin{array}{c}\text { Possible } \\
\text { volume } \\
\text { of } \\
\text { import } \\
\text { substitu } \\
\text { tion, } \\
\text { million } \\
\text { dollars. }\end{array}$ & $\begin{array}{l}\text { Type of import } \\
\text { substitution strategy }\end{array}$ \\
\hline Beef & 1161,0 & 48,0 & 116,0 & $\begin{array}{l}\text { Limited import } \\
\text { substitution }\end{array}$ \\
\hline Pork & 952,3 & 12,5 & 210,0 & $\begin{array}{l}\text { Entering foreign } \\
\text { market }\end{array}$ \\
\hline Chicken & 362,4 & 5,6 & 90, & $\begin{array}{l}\text { Entering foreign } \\
\text { market }\end{array}$ \\
\hline $\begin{array}{l}\text { Fish and fish } \\
\text { products }\end{array}$ & 1355,0 & 27,5 & 21,0 & $\begin{array}{l}\text { Entering foreign } \\
\text { market }\end{array}$ \\
\hline $\begin{array}{l}\text { Dry milk and } \\
\text { cream }\end{array}$ & 411,7 & 56,4 & 4,0 & $\begin{array}{l}\text { Limited import } \\
\text { substitution }\end{array}$ \\
\hline Butter & 306,7 & 25,5 & 43,0 & $\begin{array}{l}\text { Limited import } \\
\text { substitution }\end{array}$ \\
\hline $\begin{array}{l}\text { Cheese and } \\
\text { cottage } \\
\text { cheese }\end{array}$ & 720,2 & 23,3 & 72,0 & $\begin{array}{l}\text { Limited import } \\
\text { substitution }\end{array}$ \\
\hline $\begin{array}{l}\text { Fresh } \\
\text { vegetables }\end{array}$ & 1897,1 & 10,7 & 114,0 & $\begin{array}{l}\text { Supplementing } \\
\text { import substitution }\end{array}$ \\
\hline $\begin{array}{l}\text { Fruits and } \\
\text { berries }\end{array}$ & 3944,2 & 51,8 & 37,0 & $\begin{array}{l}\text { Supplementing } \\
\text { import substitution }\end{array}$ \\
\hline $\begin{array}{l}\text { Cereals, } \\
\text { oilseeds }\end{array}$ & 1518,4 & 0,4 & 106 & Export expansion \\
\hline Sunflower oil & 3,8 & 17,5 & 1,5 & Export expansion \\
\hline Sugar & 353,2 & 6,5 & 18,0 & $\begin{array}{l}\text { Entering foreign } \\
\text { market }\end{array}$ \\
\hline $\begin{array}{l}\text { Canned meat } \\
\text { and meat } \\
\text { products }\end{array}$ & 71,0 & - & $\begin{array}{l}\text { Entering foreign } \\
\text { market }\end{array}$ \\
\hline An imp & & 1,0 & recommended \\
\hline
\end{tabular}

An import substitution strategy is recommended for product market (beef, dry milk, cheese, butter), where there is considerable shortage of raw materials, capacity of domestic market is high, goods are rather changeable, high share of import in resources and big value of import volume, market can be characterized as increasing. The process of import substitution in such a market can be characterized as import substitution process: some countries-importers are replaced by others. Raw materials shortage and lack of the effective mechanism of government regulation of a product market limit the import substitution process.

Food embargo influenced positively growth of butter production in 2014-2015. However, the decline in production indicators in 2016 reflects accumulated problems with raw materials and demand for products. Reduction in production volume of butter is caused by decrease in real income of population and decrease in effective demand.

The lead-in of coming-in imported food also played a positive role in the development of cheese production. In 2014-2015 growth rate of cheese production in Russia was 16.5 per cent per year, having achieved 602.5 thousand t. However, a considerable production growth was achieved not only by products, substituting import, but also by producing cheaper cheese and cheese products.

A more complex situation is on beef market. Despite the gradual growth of beef production in Russia, our country is aimed at exporting beef abroad, the problem of import 
substitution is far from being solved. Russian beef market in 2016 was experiencing a considerable deficit. Imported goods on this particular product market up to 2015 exceeded domestic production. In 2015-2016 cattle meat in the whole structure of imported meat products accounted for 33-37 per cent in physical terms.

A strategy of export expansion is expedient for such product groups as cereals, oilseeds and products of their processing - seed oil, flour, croup flour. So, enlargement of export potential is assumed as logical continuation of import substitution and consequence of domestic demand exhaustion.

World market capacity, price rise for cereals, weakening of some competitors make it possible to forecast further development of export potential. Constraints in increasing export potential of cereals are high volatility of harvest and gross yields, and all that is connected with low level of resource provision and create additional risks of crops shortage. Technical and technological risks are the main constraints in production expansion. As for organizational adaptation of grain complex to conditions of export expansion implementation, from the view point of many economists, vertical coordination and integration will facilitate effectiveness of the complex [Belaya, 2016], [Carillo, 2017], [Pall, 2014]

The strategy of export expansion can be implemented on oilseed market. Already now Russia is a large exporter of fats and oils and products of their processing (export volume is twice as much as imports), which, considering conjuncture of world market, gives possibility to forecast further strengthening there.

A strategy of entering foreign market is typical of such product groups as chicken meat and pork, where threshold indicators of food security are achieved and have possibility to enter foreign market with competitive products. These sectors are the most successful examples of import substitution in Russia.

As for products of poultry farming, apart from exporting traditional meat, we may pick out production and export of halal products, possible annual export of which is estimated in $\$ 500$ mln.[Safiullin, 2016]

Far more complex situation is with fish and fish products market, where there has been a steady trend: with annual increase in fish catch, we may see annual increase in export of fish abroad. However, on the consumer market these products have gradually been substituted for imported ones with constant increase in prices. We suppose that rational import substitution and strengthening of export potential in the particular sector is much due to solving institutional and legal issues.

A strategy of supplementing import substitution can be implemented with fresh fruits and vegetables. About half of fruits and nuts import volume is represented by exotic products. At the same time, possibilities of import substitution of domestic products are considerable.

Therefore, carried out analysis shows that product groups vary considerably from the point of view of Russian producers' possibilities and import potential, including export possibilities. In the short-term run without fundamental modernization of national food system, maintaining current growth rate, import substitution volume will not exceed 0.9-1 billion dollars (considering food inflation). No doubt that both import substitution, and export expansion of Russian foodstuffs are impossible without development of innovative potential of domestic producers [Kalenskaya, Pratchenko, 2015].

Evaluation of key criteria of attractiveness of main world market segments for Russian foodstuff producers (market capacity, growth rate, price dynamics, major competitorsexporters and etc.) show that there are following attractors for development of export activity of Russian enterprises: butter and fats products market (decreased supply against the backdrop of rising prices; Russian potential exceeds world level); grain market (grain is a strategic product, necessary for solving the problem of hunger in poorest countries; its supply grows slower than needs; Russia has traditional specialized production and export of grain); meat market, pork and chicken meat in particular (favorable price dynamics; high production efficiency and increasing production potential of Russia in these sectors).

Strategic task decision of decreasing food import capacity requires a considerable time period. Performed calculations on aggregated product groups showed that for import substitution strategy realization we will need: milk - 10 years within average growth of 3.5-4 per cent a year; fruits and berries more than 15 years with yearly growth of not less than 12 per cent, which means that possibilities for achieving strategic tasks are considerably limited (table 2).

TABLE II. EVALUATION OF REQUIRED IMPORT SUBSTITUTION VOLUME AND POSSIBLE EXPORT WITHIN PRODUCT GROUPS

\begin{tabular}{|c|c|c|c|c|c|c|c|c|}
\hline \multirow[t]{2}{*}{$\begin{array}{l}\text { Product } \\
\text { group }\end{array}$} & \multicolumn{4}{|c|}{$\begin{array}{c}\text { Group 1. Considerable } \\
\text { possibilities of import } \\
\text { substitution into the world } \\
\text { market }\end{array}$} & \multicolumn{2}{|c|}{$\begin{array}{c}\text { Group II. } \\
\text { There are } \\
\text { possibilities } \\
\text { for import } \\
\text { substitution, } \\
\text { but they are } \\
\text { restricted by } \\
\text { internal } \\
\text { potential }\end{array}$} & \multicolumn{2}{|c|}{$\begin{array}{l}\text { Group III. } \\
\text { Considerable } \\
\text { restrictions } \\
\text { for import } \\
\text { substitution }\end{array}$} \\
\hline & $\begin{array}{c}\text { Seed } \\
\text { oil }\end{array}$ & Sugar & Fish & Potato & $\begin{array}{l}\text { Vegeta } \\
\text { bles } \\
\text { and } \\
\text { melon } \\
\text { crops } \\
\end{array}$ & $\begin{array}{l}\text { Meat } \\
\text { and } \\
\text { meat } \\
\text { pro- } \\
\text { ducts }\end{array}$ & $\begin{array}{l}\text { Milk } \\
\text { and } \\
\text { milk } \\
\text { pro- } \\
\text { ducts }\end{array}$ & $\begin{array}{l}\text { Fruits } \\
\text { and } \\
\text { berry }\end{array}$ \\
\hline $\begin{array}{l}\text { Demand } \\
\text { due to } \\
\text { recommen } \\
\text { ded norms } \\
\text { and } \\
\text { threshold } \\
\text { values of } \\
\text { foodstuff } \\
\text { security, } \\
\text { mln.t }\end{array}$ & 1,5 & 3,7 & 2,9 & 14,0 & 18,6 & 10,5 & 42,6 & 12,2 \\
\hline $\begin{array}{l}\text { Production, } \\
\text { mln.t }\end{array}$ & 4,7 & 5,7 & 4,4 & 33,6 & 16,1 & 9,5 & 30,8 & 3,5 \\
\hline $\begin{array}{l}\text { Import, } \\
\text { mln.t }\end{array}$ & 1,0 & 0,3 & 2,0 & - & 2,9 & 1,3 & 7,0 & 6,8 \\
\hline Import & 0,4 & 0,3 & 1,0 & - & 3,0 & 1,1 & 12,4 & 4,4 \\
\hline
\end{tabular}




\begin{tabular}{|c|c|c|c|c|c|c|c|c|}
\hline $\begin{array}{l}\text { substitution } \\
\text { volume } \\
\text { (considerin } \\
\mathrm{g} \\
\text { supplement } \\
\text { ing } \\
\text { import), } \\
\text { mln.t }\end{array}$ & & & & & & & & \\
\hline $\begin{array}{l}\text { Possible } \\
\text { export, } \\
\text { mln.t }\end{array}$ & 3,2 & - & 2,5 & - & 0,8 & 0,1 & 0,6 & 0,1 \\
\hline
\end{tabular}

Import substitution volume (considering supplementing import) and possible export in the table are calculated using the formula:

$$
\operatorname{Im}_{i}, E x_{i}=P-I D
$$

where Imi - import substitution volume;

Exi - possible export;

$\mathrm{P}$-production in the country;

ID - demand due to recommended norms and threshold values of food security.

For Russia to occupy worthy place in the world food market, production is supposed to grow intensively that means labor efficiency has to increase minimum twice. Therefore, country has to go hard way from the agricultural productive complex destroyed in the 1990s of the XX century to a stable, competitive food system of industrial type (figure 2).

\begin{tabular}{|c|c|c|}
\hline Russia-1990 & Russia-2015 & Russia-2030 \\
\hline $\begin{array}{l}\text { Value added } \\
\text { in agriculture } \\
\text { - } 3635 \$ / \text { per } \\
\text { capita }\end{array}$ & $\begin{array}{l}\text { Value added } \\
\text { in agriculture } \\
\text { - } 5973 \text { \$/per } \\
\text { capita }\end{array}$ & $\begin{array}{l}\text { Value added in } \\
\text { agriculture - not } \\
\text { less than } \mathbf{1 5 0 0 0} \\
\$ / \text { per capita }\end{array}$ \\
\hline $\begin{array}{l}\text { Food } \\
\text { production - } \\
308.35 \quad \$ / \text { per } \\
\text { capita }\end{array}$ & $\begin{array}{l}\text { Food } \\
\text { production - } \\
325.89 \quad \$ / \text { per } \\
\text { capita }\end{array}$ & $\begin{array}{l}\text { Food } \\
\text { production - } \\
\text { not less than } \\
600 \quad \$ / \text { per } \\
\text { canita }\end{array}$ \\
\hline $\begin{array}{l}\text { Food export- } \\
\text { import ratio - } \\
0.015\end{array}$ & $\begin{array}{l}\text { Food export- } \\
\text { import ratio - } \\
0.401\end{array}$ & $\begin{array}{l}\text { Food export- } \\
\text { import ratio - } \\
\text { more than } 1 .\end{array}$ \\
\hline
\end{tabular}

Fig. 2. Development of agricultural and productive system vector of Russia

\section{CONCLUSION}

Protectionist effect of embargo is a temporary effect and can not be a source of development of steady competitive advantages of domestic enterprises in medium and long-term perspective. This requires new food policy formation in Russia, based on achievement of balance between food independence and application of international division of labor advantages, as it is done in world leading economies.

Import substitution policy on the food market is implemented through different strategic alternatives applicable to particular product groups (markets). In accordance with this fact, a differentiated mechanism of such policy implementation is formed, assuming protectionism balance and free trade. Logical continuation of import substitution growth is export-oriented growth of the Russian agricultural sector, transferring to which in some types of food is possible rather soon due to the process of using up domestic demand potential.

Realization of direct protectionist measures in agricultural production complex is able to unbalance some food production segments, which may call into question strengthening of Russia's position on the world market. That is why we are of opinion that priority should be given to indirect regulatory methods, creating effective economic and financial ways of production development, restoring of domestic demand and stimulating export activity of Russian enterprises, and all this is impossible without attracting considerable investments in agricultural and labor potential development, technic and technological re-equipment of enterprises and infrastructure development.

\section{References}

[1] P.J. Ericksen, J.S.I. Ingram, D.M. Liverman, Food security and global environmental change emerging challenges, Environmental Science and Policy, Vol. 12, pp. 373-377, 2009.

[2] M. Reilly, D. Willenbockel, Managing uncertainly: a review of food system scenario analysis and modeling, Philosophical Transactions of the Royal Society B: Biological Sciences, Phil.Trans.R.Soc., 2010, 365, pp. 3049-3063. doi: 10.1098/rstb2010.0141.

[3] H.C. Godfray, I.R. Crute, L. Haddad, The future of Global food system, Philosophical Transactions of the Royal Society B: Biological Sciences, Phil.Trans.R.Soc., 2010, 365, pp. 2769-2777. doi: $10.1098 / \mathrm{rstb} 2010.0180$.

[4] M.C. Heller, G.A. Keoleain, Assessing the sustainability of the US food system: a life cycle perspective, Agricultural systems, 2003, no. 76, pp.1007-1041.

[5] R. Prebisch, The Economic Development of Latin America and Its Principal Problems, United Nations department of economic affairs, Lake Success, New York, 1950.

[6] W. Bauer, Import Substitution and Industrialization in Latin America: Experiences and Interpretations, Latin American Research Review, Vol. 7, No. 1, Spring, 1972, pp. 95-122.

[7] P. Montalbano, S. Nenci, L. Salvatici, Trade, value chains and food security, Food and Agricultural Organization of the United Nations, Rome, 2015.

[8] G. Griffith, D. Baker, E. Fleming, S. Mounter, Chain failure and chain goods: re-thinking value chain upgrading and promotion in developing countries, Journal of Food Systems Dynamic, 2017, Vol.8, № 2. doi: https://doi.org/10.18461/ijfsd.v8i2.825.

[9] P. Wehrheim, P. Wobs, The Economic role of Russia's subsistence agriculture in the transition process, Agricultural Economics, 2005, Vol. 33, Is.1, July 2005, pp. 91-105. doi: 10.1111/j.1574-0862.2005.00136.x

[10] D. Gallyamova, A. Toumashev, V. Malaev, Influence of globalization on development of the Russian economy, Mediterranean Journal of Social Sciences, no. 5, № 18, 2014, pp.133-137.

[11] V. Belaya, J.H. Hanf, Conflict resolution in vertical collaborations in the agri-food sector, Journal of Food Systems Dynamic, 2016, Vol.7, № 1. doi: https://doi.org/10.18461/ijfsd.v7i1.713

[12] F. Carillo, F. Caracciolo, L. Cembalo, Do durum wheat producers benefit of vertical coordination? Agricultural and food economics, 2017, no. 5:19. doi 10.1186/s40100-017-0088-7

[13] Z. Pall, O. Perekhozhuk, T. Glauben, S. Prehn, R. Teuber, Residual demand measures of market power of Russian wheat exporters, 
Agricultural Economics, 2014, Vol. 45, Is. 3, May 2014, pp. 381-391. doi: 10.1111/agec.12072

[14] L. N. Safiullin, G. K. Galiullina, L. B. Shabanova, State of the market production standards «halal» in Russia and Tatarstan: hands-on review, Academy of Marketing Studies Journal, 2016, Vol. 20, pp. 88-95.

[15] N.V. Kalenskaya, Analysis of the state and prospects of innovative development of the Russian economy in conditions of its modernization, Asian Social Science, 2015, Vol.11, Is.11, pp.357-363. 